\title{
Safe Surgery: What Else We Need Except Surgery
}

\author{
Pankaj Srivastava MS \\ Department of Surgery, Om Surgical Center \& Maternity Home, India
}

Submission: May 28, 2018; Published: June 08, 2018

*Corresponding author: Pankaj Srivastava, Laparoscopic, Thoracic, Thoracoscopic \& VATS Surgeon, Om Surgical Center \& Maternity Home, SA 17/3, P-4, Sri Krishna Nagar, Paharia, Ghazipur Road, Varanasi, UP, INDIA. Tel: +91-542-2586191/+919415226817; Email: drpankajbns@gmail.com

\section{Editorial}

\section{Surgeons must be very careful \\ When they take the knife! \\ Underneath their fine incisions}

Stirs the Culprit - Life!

Emily Dickinson must have had special conscious in his mind when he has written this phrase. As an ethical issue, safety is the paramount importance in treating any patient. How much a doctor can give to a patient must be weighed in terms of the risk benefit ratio because as per my thinking under correction of ailment with short productive life is far more acceptable than complete correction with a miserable long life. Being a surgeon, I completely agree with the aforesaid phrase that before putting the knife on the human body, one must think hundred times as every cut is a permanent cut and it can be healed but can never be restored as an original one. Patients allow us to cut their body in the faith that they would be cured of their ailments after getting this cut and subsequent scar over their body. They happily receive pain in the hope of future happiness and to get a disease free life. One more dictum is being still taught to all surgery residents that "Correct Incision Does Half of the Surgery" and for that we follow anatomical landmarks, Langer's line concept etc.

The literal meaning of "Safe" is "protected from or not exposed to danger or risk; not likely to be harmed or lost" or "not likely to cause or lead to harm or injury; not involving danger or risk"; therefore, if we include all these definitions and concepts with our surgery, the meaning of "Safe Surgery" amounts too much on the shoulders of surgeons and their operating team. As such, no one should draw inference that safety is somewhat very peculiar type of thing that is to be taught in a very special manner. It is literally infused in our veins in our entire medical profession, especially in surgical residency programs. We use some terms which are self explanatory that care is in the back of our mind at every step of patient treatment like preoperative care, postoperative care etc.

\section{Surgical Safety Checklist}

\begin{tabular}{|c|c|c|}
\hline Before induction of anaesthesia & Before skin incision & Before patient leaves operating room \\
\hline (with at least nurse and anaesthetist) & (with nurse, anaesthetist and surgeon) & (with nurse, anaesthetist and surgeon) \\
\hline $\begin{array}{l}\text { Has the patient confirmed his/her identity, } \\
\text { site, procedure, and consent? }\end{array}$ & $\begin{array}{l}\square \text { Confirm all team members have } \\
\text { introduced themselves by name and role. }\end{array}$ & \multirow{4}{*}{$\begin{array}{l}\text { Nurse Verbally Confirms: } \\
\square \text { The name of the procedure } \\
\square \text { Completion of instrument, sponge and needle } \\
\text { counts } \\
\square \text { Specimen labelling (read specimen labels aloud, } \\
\text { including patient name) } \\
\square \text { Whether there are any equipment problems to be } \\
\text { addressed }\end{array}$} \\
\hline$\square$ Yes & $\square$ Confirm the patient's name, procedure, & \\
\hline $\begin{array}{l}\text { Is the site marked? } \\
\square \text { Yes }\end{array}$ & \multirow{2}{*}{$\begin{array}{l}\text { Has antibiotic prophylaxis been given within } \\
\text { the last } 60 \text { minutes? } \\
\square \text { Yes } \\
\square \text { Not applicable }\end{array}$} & \\
\hline $\begin{array}{l}\square \text { Not applicable } \\
\text { Is the anaesthesia machine and medication }\end{array}$ & & \\
\hline $\begin{array}{l}\text { check complete? } \\
\square \text { Yes }\end{array}$ & \multirow{7}{*}{$\begin{array}{l}\text { Anticipated Critical Events } \\
\text { To Surgeon: } \\
\square \text { What are the critical or non-routine steps? } \\
\square \text { How long will the case take? } \\
\square \text { What is the anticipated blood loss? } \\
\text { To Anaesthetist: } \\
\square \text { Are there any patient-specific concerns? } \\
\text { To Nursing Team: } \\
\square \text { Has sterility (induding indicator results) } \\
\text { been confirmed? } \\
\square \text { Are there equipment issues or any concerns? }\end{array}$} & \multirow{10}{*}{$\begin{array}{l}\text { To Surgeon, Anaesthetist and Nurse: } \\
\square \text { What are the key concerns for recovery and } \\
\text { management of this patient? }\end{array}$} \\
\hline $\begin{array}{l}\text { Is the pulse oximeter on the patient and } \\
\text { functioning? } \\
\square \text { Yes }\end{array}$ & & \\
\hline Does the patient have a: & & \\
\hline Known allergy? & & \\
\hline$\square$ No & & \\
\hline$\square$ Yes & & \\
\hline $\begin{array}{l}\text { Difficult airway or aspiration risk? } \\
\square \text { No }\end{array}$ & & \\
\hline$\square$ Yes, and equipment/assistance available & \multirow{3}{*}{$\begin{array}{l}\text { Is essential imaging displayed? } \\
\square \text { Yes } \\
\square \text { Not applicable }\end{array}$} & \\
\hline $\begin{array}{l}\text { Risk of }>500 \mathrm{ml} \text { blood loss }(7 \mathrm{ml} / \mathrm{kg} \text { in children)? } \\
\text { No }\end{array}$ & & \\
\hline $\begin{array}{l}\square \text { Yes, and two IVs/central access and fluids } \\
\text { planned }\end{array}$ & & \\
\hline
\end{tabular}

Figure 1: WHO Surgical Saftey Checklist 2009. 
safety measures of health care and patient monitoring system [1]. Safety of surgical care was chosen in 2007-2008 as second global patient safety challenge. The WHO Surgical Checklist is intended to give surgical teams a simple and efficient set of priority checks to ensure patient safety, effective teamwork, and communication in every operation performed [2]. These types of surgical check lists (Figure 1) are the best guide to avoid missing factors by the staff, doctors, anesthestists and all the related paramedics [3].

In fact, to rember huge list of 'to do' is not practically possible for anyone. From ages, paramedical staff have been following the written orders of the doctors one by one but in the present scenario it is very difficult to scrutinize every minute thing in a hospital particularly those are dealing with heavy work load. So by putting some extra surveillance paramedical staff, these health hazards can be minimized. These special staff should be responsible for the proper completion of the recommended checklist pre- and postoperative periods. These staff should not be a part of operating team as those are already concentrating their routine job and if at all these checklists be given to them, they consider overburdened and at times loosely handle the alert flags which in turn leads to hazard. That's why it is considered that the checklists can be completed thoroughly only if the surgeon and the anesthesiologist are supportive [4].

Conclusively in my recommendation, the most important factor to do safe surgery is the correct diagnosis; others include essential mandatory and ancillary investigations; proper understanding of the disease and the operative procedure by the operating team including anesthetist, assistants, scrub nurses and supporting staffs; proper anticipation of the procedure related complications and their in time redressal; availability of all the essential and supporting medicines, surgical goods and instruments; critical reevaluation of the surgical steps after sometime in long surgeries; unbiased evaluation of surgeon's own capacity of dealing with the ongoing unavoidable situations and managing the complication if at all occurred; and last but not the least is to take help from fellow competent surgeon without hesitation and ego as taking advise and help from the fellows should not be considered as failure likewise in laparoscopy surgery every stalwart says that conversion to open surgery from laparoscopic procedure should not be taken as failure rather it should be considered as the wisest decision taken by the honest surgeon because safe surgery is more important than laparoscopic surgery. Bottom line of all discussion is that before being a good surgeon we must be the good human being.

\section{References}

1. (2009) World Health Organization Safe Surgery Saves Lives.

2. Jain D, Sharma R, Reddy S (2018) WHO safe surgery checklist: Barriers to universal acceptance. J Anaesthesiol Clin Pharmacol 34(1): 7-10.

3. (2009) World Health Organization. Safe Surgery Saves Lives. Implementation manual WHO surgical safety checklist.

4. Vats A, Vincent CA, Nagpal K, Davies RW, Darzi A, et al. (2010) Practical challenges of introducing WHO surgical checklist: UK pilot experience. BMJ 340: b5433.

Your next submission with Juniper Publishers will reach you the below assets

- Quality Editorial service

- Swift Peer Review

- Reprints availability

- E-prints Service

- Manuscript Podcast for convenient understanding

- Global attainment for your research

- Manuscript accessibility in different formats ( Pdf, E-pub, Full Text, Audio)

- Unceasing customer service

Track the below URL for one-step submission https://juniperpublishers.com/online-submission.php 